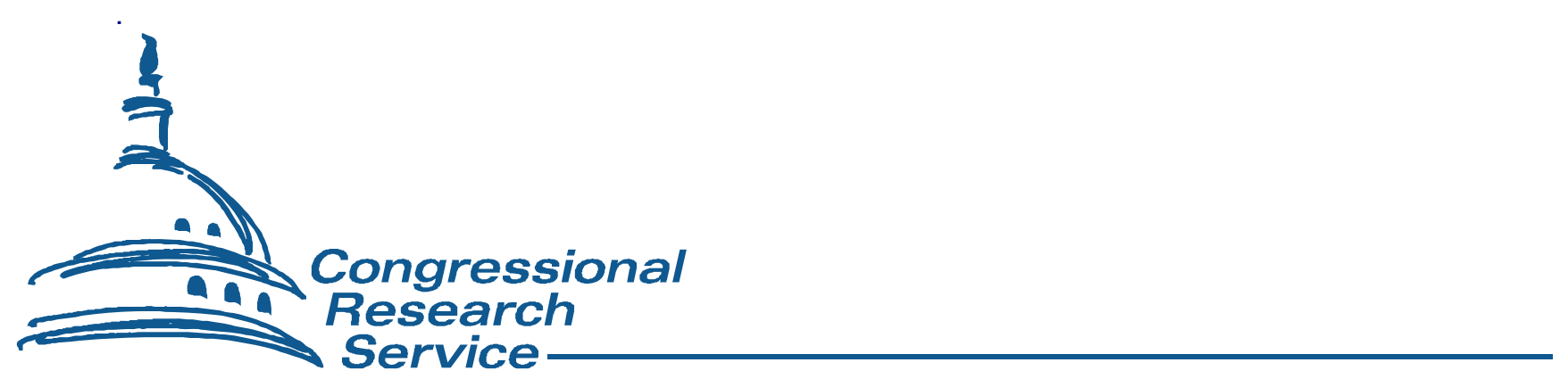

\title{
The U.S. Newspaper Industry in Transition
}

\author{
Suzanne M. Kirchhoff
}

Analyst in Industrial Organization and Business

January 11, 2011

Congressional Research Service 


\section{Summary}

The U.S. newspaper industry is suffering through what could be its worst financial crisis since the Great Depression. Advertising revenues have plummeted due in part to the severe economic downturn, while readership habits have changed as consumers turn to the Internet for free news and information. Some major newspaper chains are burdened by heavy debt loads. Between 2008 and early 2010, eight major newspaper chains declared bankruptcy, several big city papers shut down, and many laid off reporters and editors, imposed pay reductions, cut the size of the physical newspaper, or turned to Web-only publication.

Newspaper publishers during 2010 saw some improvement in financial conditions, with many reporting higher profits, but the industry had not yet turned the corner. Advertising dollars were still declining and newspapers had not found a stable revenue source to replace them. As the problems continue, there are growing concerns that the decline of the newspaper industry will impact civic and social life. Already there are fewer newspaper reporters covering state capitols and city halls, while the number of states with newspapers covering Congress full-time dwindled to 23 in 2008 from the most recent peak of 35 in 1985.

As old-style, print newspapers decline, new journalism startups are developing around the country, aided by low entry costs on the Internet. The emerging ventures hold promise but do not yet have the experience, resources, and reach of shrinking mainstream newspapers.

Congress has begun debating whether the financial problems in the newspaper industry pose a public policy issue that warrants federal action. Whether a congressional response to the current turmoil is justified may depend on the current causes of the crisis. If the causes are related to significant technological shifts (the Internet, smart phones and electronic readers) or societal changes that are disruptive to established business models and means of news dissemination, the policy options may be quite limited, especially if new models of reporting (and, equally important, advertising) are beginning to emerge. Governmental policy actions to bolster existing businesses could stall or retard such a shift. In this case, policymakers might stand back and allow the market to realign news gathering and delivery, as it has many times in the past. If, on the other hand, the current crisis is related to the struggle of some major newspapers to survive the current recession, possible policy options to ensure the continuing availability of in-depth local and national news coverage by newspapers might include providing tax breaks, relaxing antitrust policy, tightening copyright law, providing general support for the practice of journalism by increasing funding for the Corporation for Public Broadcasting (CPB) or similar public programs, or helping newspapers reorganize as nonprofit organizations. Policymakers may also determine that some set of measures could ease the combination of social and technological transition and the recession-related financial distress of the industry. 


\section{Contents}

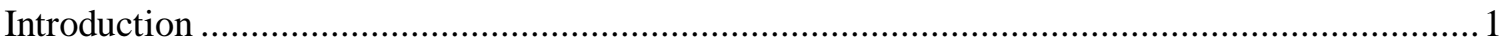

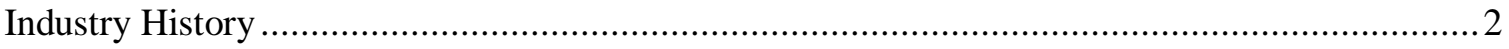

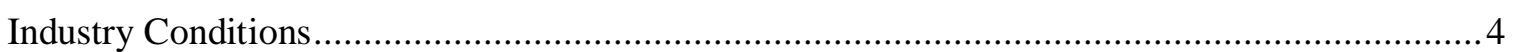

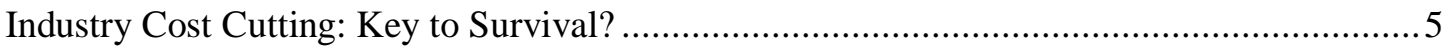

Declining Advertising Revenues, Recession, and the Internet ..........................................

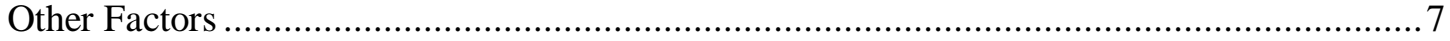

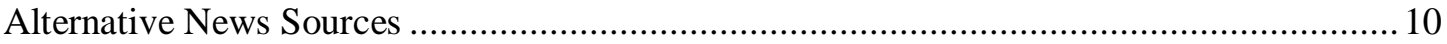

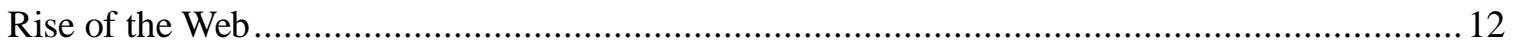

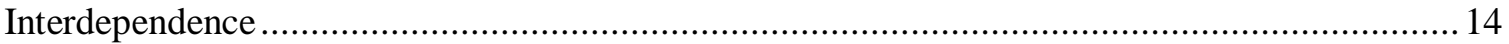

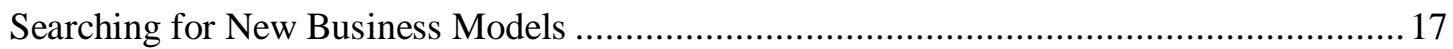

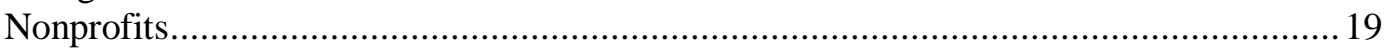

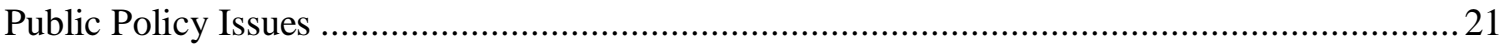

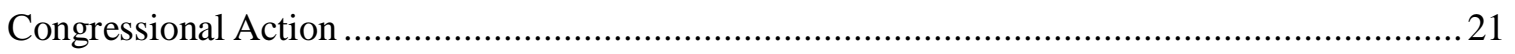

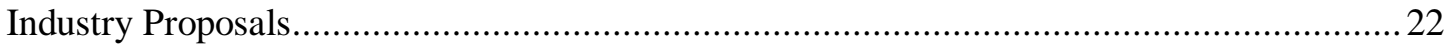

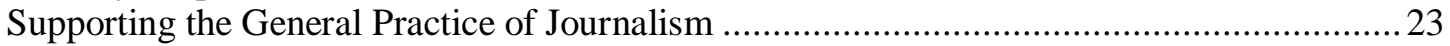

\section{Figures}

Figure 1. Percent Change in 2009 Media Ad Revenues, by Publication......................................6

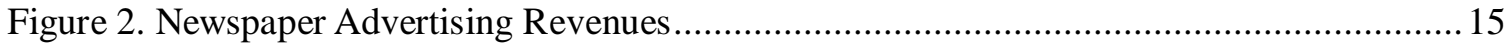

\section{Tables}

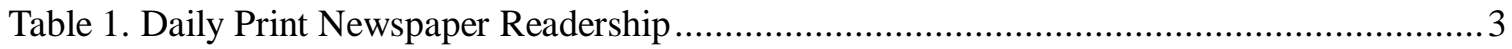

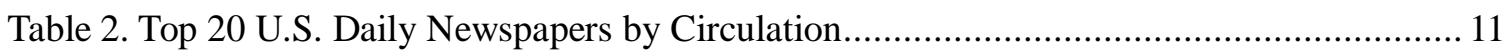

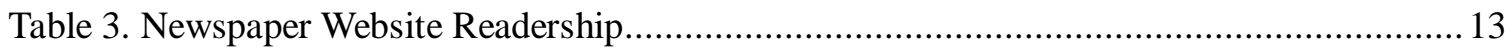

\section{Contacts}

Author Contact Information 


\section{Introduction}

The U.S. newspaper industry is in the midst of a historic restructuring, buffeted by a deep recession that has battered crucial advertising revenues, long-term structural challenges as readers turn to free news and entertainment on the Internet, and heavy debt burdens weighing down some major media companies. Eight major U.S. newspaper companies filed for bankruptcy between 2008 and early 2010 (though nearly all have since emerged as reorganized companies), while hundreds of smaller papers went out of business or moved to Web-only publications. Concerned about the potential loss of independent news outlets, lawmakers during the $111^{\text {th }}$ Congress debated legislation to assist the industry. Additionally, the Federal Trade Commission (FTC) held a series of workshops beginning in December 2009 to look at challenges facing newspapers, television, and radio in the Internet age. ${ }^{1}$

Publishers are experimenting with new business approaches, but there is no widely agreed-upon model to restore the link between newspaper content and earnings, which has been partially severed on the Internet. Newspapers historically have depended on advertising for about $80 \%$ of revenues. Even after investing major sums in technology, and attracting millions of online readers, only about $10 \%$ of overall newspaper ad dollars was Internet-driven in $2009 .{ }^{2}$ At the same time, print readership is falling, further cutting into subscription and advertising revenues (see Table 1). Vin Crosbie, a noted Syracuse University professor and consultant, has predicted that more than half of the approximately 1,400 daily newspapers in the country could be out of business by the end of the next decade. ${ }^{3}$

Concerns extend beyond the tens of thousands of reporters and editors losing their jobs. A robust, free press has been viewed by many as an essential check on government and business since the early days of the Republic. "The only security of all is in a free press," Thomas Jefferson wrote in 1823. ${ }^{4}$ House Speaker Nancy Pelosi, in a March letter to the Justice Department, argued that current problems in the newspaper sector pose a significant challenge to democracy. ${ }^{5}$

Despite First Amendment sensitivities, Congress has intervened in the past to assist newspapers and other media, building a broad record of regulation and support. Federal actions include the 1970 Newspaper Preservation Act, providing limited exemption from antitrust law; laws allocating the public airwaves $;{ }^{6}$ copyright and fair content regulation; ${ }^{7}$ postal subsidies; $;$ and

\footnotetext{
${ }^{1}$ Federal Trade Commission, "From Town Criers to Bloggers: How Will Journalism Survive the Internet Age?" Workshop Transcript, June 15, 2010, http://www.ftc.gov/opp/workshops/news/jun15/100615transcript.pdf.

${ }^{2}$ Newspaper Association of America, "Trends and Numbers, Advertising Expenditures," http://www.naa.org/ TrendsandNumbers/Advertising-Expenditures.aspx. The percentage of newspaper advertising derived from Web operations rose to $12 \%$ in the second quarter of 2010 .

${ }^{3}$ Crosbie, Vin, "Transforming American Newspapers," Corante, August 20, 2008. http://rebuildingmedia.corante.com/ archives/2008/08/20/transforming_american_newspapers_part_1.php.

${ }^{4}$ Thomas Jefferson to Lafayette, 1823. The Writings of Thomas Jefferson, Memorial Edition (Lipscomb and Bergh, editors) 20 Vols., Washington, D.C., 1903-04, Vol. 15, p. 491. See University of Virginia Library, Thomas Jefferson Digital Archive, Freedom of the Press. http://etext.virginia.edu/jefferson/quotations/jeff1600.htm\#Top.

${ }^{5}$ Letter from Nancy Pelosi, Speaker of the House, to the Honorable Eric Holder, Attorney General, March 16, 2009.

${ }^{6}$ CRS Report R40009, Fairness Doctrine: History and Constitutional Issues, by Kathleen Ann Ruane.

${ }^{7}$ CRS Report R40194, The Google Library Project: Is Digitization for Purposes of Online Indexing Fair Use Under Copyright Law?, by Kate M. Manuel.

${ }^{8}$ CRS Report R40162, Postage Subsidies for Periodicals: History and Recent Developments, by Kevin R. Kosar.
} 
financial aid through the Corporation for Public Broadcasting (CPB) and indirectly through the National Endowment for the Humanities (NEH). ${ }^{9}$ According to one study, the federal, state, and local governments provided more than $\$ 1$ billion to the news media in 2009 via tax policy, postal subsidies, and legal requirements to disseminate public notices in print, though the level of support has declined in recent years. ${ }^{10}$ Congress has ratified treaties governing fair use of intellectual property on the Internet, ${ }^{11}$ and, in the $111^{\text {th }}$ Congress, the House considered and passed the Free Flow of Information Act of 2009 (H.R. 985) to give journalists a right to withhold information in grand jury proceedings. ${ }^{12}$

Congress during the $111^{\text {th }}$ Congress debated whether financial problems, which have been most acute at large, general-interest daily papers, posed a public policy issue that required federal action. The debate is expected to continue during the $112^{\text {th }}$ Congress. If the answer is "yes," options might include aiding existing newspapers as they grapple with the transition to a digital news world; supporting the practice of journalism writ large; or taking a hands-off approach to allow what might arguably be a major social, political, and technological realignment in the way Americans choose to inform themselves about local, state, and national news. Lawmakers have so far expressed little interest in a broad bailout of the industry, similar to aid for the automobile or financial sectors. Senator Benjamin Cardin, who introduced S. 673 during the $111^{\text {th }}$ Congress to make it easier for newspapers to reorganize as nonprofit organizations, has said he does not support a financial rescue for newspapers. ${ }^{13}$

There are critics of government action. Ken McIntyre, of the Heritage Foundation, has argued that nonprofit status could "de-fang" the press, by preventing newspapers from endorsing candidates or taking positions against whatever political party was in power. ${ }^{14}$ McIntyre endorses the concept of a technology shift of Gutenberg proportions, citing media expert Clay Shirky: “... We're collectively living through 1500, when it's easier to see what's broken than what will replace it ... Society doesn't need newspapers. What we need is journalism." 15

\section{Industry History}

The newspaper industry has gone through prior periods of boom and bust. The popular press took off in the 1830s with the creation of the so-called penny press: inexpensive papers that were sold by street vendors, instead of the previous up-front subscription model. ${ }^{16}$ The industry grew in

\footnotetext{
${ }^{9}$ CRS Report RS22168, The Corporation for Public Broadcasting: Federal Funding and Issues, by Glenn J. McLoughlin and Mark Gurevitz.

${ }^{10}$ Geoffrey Cowan and David Westphal, USC Annenberg School for Communication \& Journalism, Public Policy and Funding the News, January, 2010, p. 2, http://communicationleadership.usc.edu/pubs/Funding\%20the\%20News.pdf; David Westphal, “American government: It's always subsidized commercial media," OJR: The Online Journalism Review, November 30, 2009, http://www.ojr.org/ojr/people/davidwestphal/200911/1801/.

${ }^{11}$ CRS Report RL34292, Intellectual Property Rights and International Trade, by Shayerah Ilias and Ian F. Fergusson.

${ }^{12}$ CRS Report RL34193, Journalists' Privilege: Overview of the Law and Legislation in the $110^{\text {th }}$ and $111^{\text {th }}$ Congresses, by Kathleen Ann Ruane.

${ }^{13}$ Cardin, Benjamin, “A Plan to Save Our Free Press," Washington Post, April 3, 2009, p. A19.

${ }^{14}$ McIntyre, Ken, "Death of Newspapers Does Not Mean the End of Journalism," U.S. News and World Report, May 8, 2009.

${ }^{15}$ Ibid.

${ }^{16}$ Emery, Edwin and Michael Emery, The Press and America: An Interpretive History of the Mass Media, Fourth Edition. Englewood Cliffs, NJ: Prentice-Hall, 1978. pp, 119-123.
} 
importance, profitability, and influence, including the rise of sensationalistic "yellow journalism" in the late 1800 s.

During the Great Depression, plunging revenues and competition from the emerging technology of radio hurt newspapers. Newspaper advertising revenue fell 45\% from 1929 to 1933, and was still down $20 \%$ in 1941 . Hundreds of newspapers went out of business or suspended operations, while a third of newspaper salaried workers lost their jobs. Radio increased in importance and was the only media segment that realized gains in advertising during the Depression. ${ }^{17}$

With the rise of television, the newspaper business faced another major transformation. In the 1960s, television surpassed newspapers as a source of information, and TV networks became more adept at capturing national advertising. ${ }^{18}$ Thereafter, the newspaper sector consolidated as family-owned papers were bought by growing chains. Between 1960 and 1980, 57 newspaper owners sold their properties to Gannett Co. By 1977, 170 newspaper groups owned two-thirds of the country's 1,700 daily papers. From 1969 to 1973, 10 newspaper companies went public, including the Washington Post Co., New York Times Co., and Times Mirror Co. ${ }^{19}$

Table I. Daily Print Newspaper Readership Percentage of Total Adults Who Read a Print Newspaper on a Weekday

\begin{tabular}{cccc}
\hline Year & Percentage of Total Adults & Percentage of Men & Percentage of Women \\
\hline 1998 & 58.6 & 62.2 & 55.2 \\
1999 & 56.9 & 60.6 & 53.4 \\
2000 & 55.1 & 58.8 & 51.7 \\
2001 & 54.3 & 57.5 & 51.3 \\
2002 & 55.4 & 58.2 & 52.8 \\
2003 & 54.1 & 56.8 & 51.5 \\
2004 & 52.8 & 55.5 & 50.2 \\
2005 & 51.6 & 54.1 & 49.2 \\
2006 & 49.9 & 52.3 & 47.6 \\
2007 & 48.4 & 51.0 & 45.9 \\
\hline
\end{tabular}

Source: Scarborough Research, Top 50 Market Report 1998-2007, prepared by Newspaper Association of America.

As chain ownership grew an increasing number of cities became one-paper towns, leading to concerns about lack of competition and a diminished watchdog role for the media-similar to worries voiced today. In 1910, nearly $60 \%$ of cities had competing daily papers. By 1930, that figure had fallen to $21 \%$, and by 1971 to $2 \% .^{20}$

${ }^{17}$ Ibid., pp. 399-400, p. 428, p. 436.

${ }^{18}$ Matthei, Harry, "Inventing the Commercial: the imperium of modern television advertising was born in desperate improvisation," American Heritage, May/June 1997, Volume 48, Issue 3.

${ }^{19}$ Neiva, Elizabeth M., "Chain Building: The Consolidation of the American Newspaper Industry, 1955-1980," Business and Economic History, Volume 24, No. 1, Fall 1995.

${ }^{20}$ Report of the Assistant Attorney General in Charge of the Antitrust Division, In the Matter of: Application by the E.W. Scripps Co. and MediaNews Group Inc. For Approval of a Joint Operating Agreement Pursuant to the Newspaper (continued...) 
Some local papers around the country tried to combat the economic stresses by pooling advertising and circulation operations. The U.S. Supreme Court in the 1969 decision United States v. Citizen Publishing Co. ruled against such arrangements. In response, Congress passed the Newspaper Preservation Act of 1970 (P.L. 91-353; 15 U.S.C. 43). ${ }^{21}$ The law provided a limited antitrust exemption for certain newspapers that combined financial functions but maintained separate newsrooms. While there were 25 to 30 such agreements in force at any one time in recent decades, just a handful remain today, and they have not been sufficient to save some weakening newspapers. ${ }^{22}$ The Seattle Post-Intelligencer, Minneapolis Star Tribune, Rocky Mountain News, and Tucson Citizen-papers that were part of joint operating agreementsrecently closed, declared bankruptcy, or moved to Web-only production.

The increasing importance of cable television in the 1980s had a far-reaching impact on newspapers, as consumers turned to 24-hour cable news stations for information. Still, many newspapers continued to enjoy extremely profitable, quasi-monopoly status in their communities. Major newspaper companies posted double-digit returns on equity (profit compared to average shareholder equity) through most of the current decade. Profits peaked at $22.7 \%$ in 2000 and declined to just over $10 \%$ in 2008 , as newspaper companies instituted severe budget cuts and layoffs. ${ }^{23}$ Cash flow margins for big, public newspaper companies reached their high in the late 1990 s at $29 \%$, an average that declined to $13 \%$ in 2008 with large differences from paper to paper. $^{24}$

\section{Industry Conditions}

There are now about 1,400 daily newspapers in the United States and thousands of community papers, which generally publish weekly or biweekly. A handful of papers, including the Wall Street Journal, USA TODAY, and the New York Times, have a national print readership topping a million or more. ${ }^{25}$ The top 50 papers account for about a third of circulation, among them the big city papers that have had some of the largest circulation declines. ${ }^{26}$ Overall, the newspaper industry, including printers, reporters, advertising salespeople and other personnel, was a roughly $\$ 50$ billion business in 2002, according to Census Bureau data, employing about 400,000 people. $^{27}$

(...continued)

Preservation Act, File No. 44-03-24-15 (September 8, 2000), p. 16-17.

${ }^{21}$ Ibid.

${ }^{22}$ Jones, Fredrick, “The Newspaper Preservation Act: Is it a Necessary Loophole in Antitrust Laws?,” paper presented at the Annual Meeting of the Association for Education in Journalism, August 8-11, 1981. Farhi, Paul, "The Death of the JOA,” American Journalism Review, September 1999.

${ }^{23}$ Morton, John, "Not Dead Yet," American Journalism Review, June/July 2009 issue.

${ }^{24}$ Fine, Lauren Rich, "Bad Public Relations or Is This a Real Crisis?: YES,” Duke Conference on Nonprofit Media, May 4-5, 2009. http://www.pubpol.duke.edu/nonprofitmedia/documents/dwcrichfinefinal.pdf.

${ }^{25}$ Audit Bureau of Circulations, "Circulation Averages for the Six Months Ended March 31, 2010, http://abcas3.accessabc.com/ecirc/newstitlesearchus.asp.

${ }^{26}$ Pew Research Center's Project for Excellence in Journalism, The State of the News Media 2009: An Annual Report on American Journalism. http://www.stateofthemedia.org/2009/index.htm.

${ }^{27}$ U.S. Census Bureau, Industry Statistics Sampler, NAICS 511110, Newspaper Publishers. 


\section{Industry Cost Cutting: Key to Survival?}

For the traditional, general-interest print newspapers analyzed in this report, labor has made up about $50 \%$ of costs, with production and distribution accounting for 30\% and other expenses for the rest. ${ }^{28}$ Newspapers have taken dramatic steps to cut costs as their financial picture has worsened, including trimming the size of the print newspaper, eliminating staff, or reducing the number of days the print newspaper is delivered to subscribers.

Daily papers cut their newsrooms by $11 \%$, or 6,000 full-time workers, in 2008 , the biggest oneyear drop since 1978. Newspaper publishers reduced newsroom staff by another 5,200 jobs in 2009 , for a total reduction in daily newsroom staffing of more than $25 \%$ from the recent 2001 peak of 56,400. ${ }^{29}$ According to Erica Smith, a reporter with the St. Louis Post-Dispatch, more than 2,200 workers at U.S. newspapers were laid off or took buyouts in the first eight months of $2010 .^{30}$ The number of reporters covering state legislatures in 2009 was down more than $30 \%$ from 2003. ${ }^{31}$

The Regional Reporters Association, an organization of newspaper journalists assigned to cover Washington, DC, has seen its membership decline from more than 200 a decade ago to about 55 today. ${ }^{32}$ For example, roughly 10 years ago, 15 regional reporters covered Congress and other federal agencies for Connecticut-based newspapers. In 2009 there were none, according to the U.S. Senate Daily Press Gallery. (The Gallery in 2010 approved press credentials for a reporter for a startup online news organization, the Connecticut Mirror.) The Dallas Morning News Bureau has shrunk from 11 reporters in Washington, DC, to three, according to the American Journalism Review, ${ }^{33}$ which in a recent study of the Washington press corps also noted that the Newhouse, Cox, and Media General newspaper chains closed their capital bureaus in recent years. ${ }^{34}$

\section{Declining Advertising Revenues, Recession, and the Internet}

Retail, classified, and national ads have traditionally accounted for $80 \%$ of newspaper revenues, with subscriptions and newsstand sales making up most of the rest. Sunday newspapers, with

\footnotetext{
${ }^{28}$ Fine, Lauren Rich, "Bad Public Relations or Is This a Real Crisis?: YES,” Duke Conference on Nonprofit Media, May 4-5, 2009.

29 "Decline in newsroom jobs slows," American Society of News Editors, April 11, 2010. http://asne.org/article_view/ articleid/763/decline-in-newsroom-jobs-slows.aspx.

${ }^{30}$ Johnston, David Cay, "Welcome to the Jungle: Journalists, meet the all-or-nothing job market," Columbia Journalism Review, May 22, 2009; Smith, Erica, "Layoffs and buyouts at U.S. newspapers in 2009," Paper Cuts. http://graphicdesignr.net/papercuts.

${ }^{31}$ Dorroh, Jennifer, “Statehouse Exodus,” American Journalism Review, April/May 2009. http://www.ajr.org/ Article. asp?id=4721.

${ }^{32}$ Interview with Thomas Burr of the Salt Lake Tribune, president of the Regional Reporters Association, June 3, 2010. Journalists pay a $\$ 20$ fee to join the RRA. All reporters who cover Washington for out-of-town publications may not necessarily be members of the group. For example, Associated Press reporters who cover state congressional delegations, in addition to other subjects, may not choose to join.

33 Jodi Enda, “Capital Flight,” American Journalism Review, June/July 2010, http://ajr.org/Article.asp?id=4877.

${ }^{34}$ Ibid.
} 
their bulky ad inserts and extra sections, along with papers published later in the week, have brought in more than half of newspaper print dollars at some publications. ${ }^{35}$

The traditional advertising model for years generated healthy profits, subsidized expensive foreign, investigative, and other reporting and helped keep subscription and newsstand prices low. But the model is breaking down. Newspapers have seen a dramatic drop in advertising during the recession. While other media have also been hurt, newspapers have had some of the sharpest declines (see Figure 1). Total advertising revenue at daily newspapers plunged from $\$ 49.4$ billion in 2005 to $\$ 27.6$ billion in $2009-a$ a $44 \%$ decrease. $^{36}$

The Pew Center's Project for Excellence in Journalism in 2009 estimated that about half of the recent drop in advertising was due to the poor economy, as auto dealers went out of business and other retailers cut back. But it is not clear that most of those ad dollars will come back as business activity revives. ${ }^{37}$

Figure I. Percent Change in 2009 Media Ad Revenues, by Publication January-September 2009, compared to January-September 2008

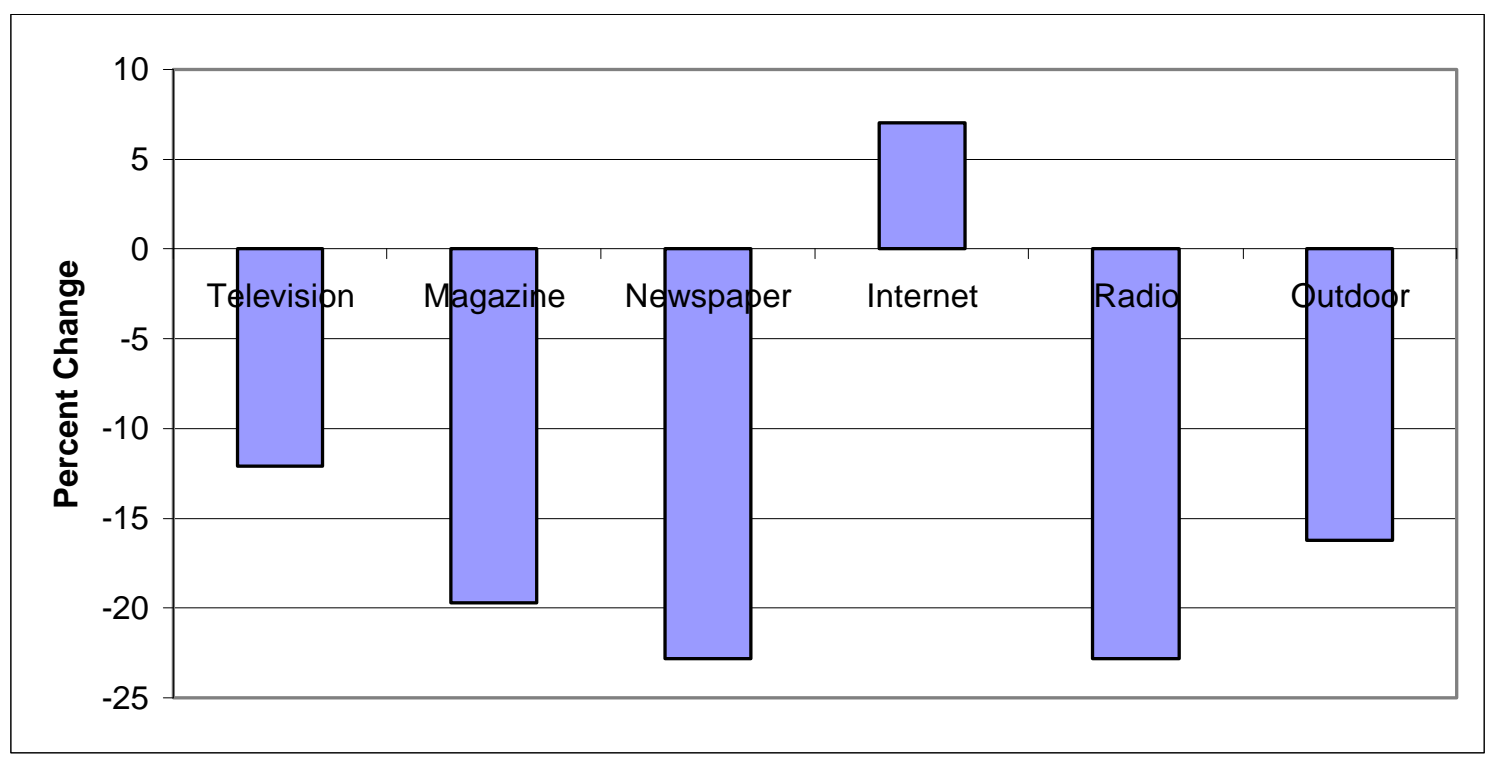

Source: TNS Media Intelligence.

Notes: Overall U.S. media ad spending declined by $14.7 \%$ in the first nine months of 2009. More recent TNS data indicate that media spending increased in the first quarter of 2010, compared to the same period in 2009.

\footnotetext{
${ }^{35}$ Pew Research Center's Project for Excellence in Journalism, The State of the News Media 2009: An Annual Report on American Journalism, http://www.stateofthemedia.org/2009/index.htm.

${ }^{36}$ Newspaper Association of America, "Trends and Numbers, Advertising Expenditures,” http://www.naa.org/ TrendsandNumbers/Advertising-Expenditures.aspx.

${ }^{37}$ Pew Research Center's Project for Excellence in Journalism, The State of the News Media 2009: An Annual Report on American Journalism.
} 
Newspapers are also in the throes of long-term, structural changes as readers and advertisers move to the Internet. While newspapers' online presence is surging, Internet revenues lag far behind Internet readership. Online ad revenues made up about $10 \%$ of newspaper advertising in 2009 , a figure that rose to about $12 \%$ during the second quarter of $2010 .^{38}$

In one example, classified advertising, which accounted for about $50 \%$ of ad revenues for many papers at its peak in 2008, ${ }^{39}$ has gravitated from print to specialized websites like Craigslist and auto, real estate, and help wanted sites. ${ }^{40}$ Media companies have tried various strategies to hold on to the classified market, with big chains like McClatchy, the Tribune Co., the Washington Post Co., A.H. Belo, and Gannett Co. jointly owning Classified Ventures, which runs sites like cars.com and homegain.com. ${ }^{41}$ A coalition of media firms created CareerBuilder.com, a job placement site. ${ }^{42}$ The sour economy has, at least temporarily, undercut those efforts, with the volume of classified ads plunging online and in print. Nationally, classified advertising in daily papers declined $38 \%$ in 2009, with some categories falling even faster. Help-wanted ads fell $64 \%$ in 2009 compared to the previous year. ${ }^{43}$

More broadly, the traditional formula- $80 \%$ of newspaper revenues from advertising-is no longer holding steady as newspapers try new strategies to raise revenue, such as sharply increasing the price of the print newspaper, starting affiliated websites, and other strategies. At some newspapers, advertising now makes up only about one-half to two-thirds of revenues. ${ }^{44}$

\section{Other Factors}

Another reason the newspaper industry is in trouble: red ink. Some large newspaper companies took on significant debt shortly before the economic downturn hit. Real estate developer Sam Zell, for instance, took the Tribune Co.- one of the nation's most prominent newspaper chainsprivate in 2007 in a leveraged $\$ 8.2$ billion deal he later called a mistake. ${ }^{45}$ The Tribune Co., now in bankruptcy, has imposed large staff reductions, consolidated operations, and taken other steps to reorganize. In 2006, McClatchy Co. bought newspaper chain Knight Ridder for more than $\$ 4$ billion. In May 2009, the company offered to buy back more than $\$ 1$ billion of its debt at a discount. $^{46}$

\footnotetext{
${ }^{38}$ Newspaper Association of America, “Trends and Numbers, Advertising Expenditures," http://www.naa.org/ TrendsandNumbers/Advertising-Expenditures.aspx.

${ }^{39}$ Fine, Lauren Rich, "Bad Public Relations or Is This a Real Crisis?: YES," Duke Conference on Nonprofit Media, May 4-5, 2009, p. 11.

${ }^{40}$ Vogel, Harold L., Entertainment Industry Economics: A Guide for Financial Analysis, Sixth Edition, Cambridge: University Press, 2004, p. 318.

${ }^{41}$ Learmonth, Michael, "Newspapers Build Digital Portfolios,” Advertising Age, May 5, 2009.

${ }^{42}$ Gannett, the Tribune Co., McClatchy, and Microsoft own Careerbuilder.com. http://www.careerbuilder.com/share/ aboutus/profile_main.aspx.

${ }^{43}$ National Newspaper Association, “Trends and Numbers, Advertising Expenditures,” http://www.naa.org/ TrendsandNumbers/Advertising-Expenditures.aspx.

${ }^{44}$ Ken Doctor, "The Newsonomics of the fading 80/20 rule," Nieman Journalism Lab, August 5, 2010, http://www.niemanlab.org/2010/08/the-newsonomics-of-the-fading-8020-rule/.

${ }^{45}$ Miles, Greg and Brian Louis, "Billionaire Zell Says 'I Made a Mistake' in Purchasing Tribune," Bloomberg.com, April 15, 2009.

${ }^{46}$ McClatchy Co., "McClatchy announces private debt exchange offer for $\$ 1.150$ billion of debt securities," Press Release, May 21, 2009.
} 
Investors have soured on newspapers. Some large newspaper companies saw their stock prices drop by more than $80 \%$ in 2008 - far beyond the overall decline in the publishing industry and various stock indices. ${ }^{47}$ Stock prices regained some ground in 2009 and 2010, but were still well under previous peaks. For example, the New York Times Co. stock price rose from less than $\$ 4$ in early 2009 to $\$ 14$ a share early in 2010, before declining to about $\$ 8$ a share in September. Still, even the recent peak was well below the $\$ 32$ level of 2005.

With revenues declining and their ability to raise new capital impaired, some newspaper companies have been in danger of breaching financing agreements with their lenders. If that happens, lenders could terminate lines of credit and call in existing loans. Lee Enterprises, a newspaper publishing company based in Davenport, Iowa, in its first quarter 2009 report, noted that to secure new lines of credit, it had agreed, among other things, to limit capital spending. ${ }^{48}$ In 2010, Lee said it had been able to meet all its financial covenants, and expected to keep repaying debt mainly with cash flow. ${ }^{49}$

In a last-ditch bid to remain viable, a number of major newspaper companies declared bankruptcy between 2008 and 2010. Most have emerged from the bankruptcy process, several after being purchased by hedge funds with little prior experience in the news business. Some companies that bought the reorganized newspaper companies do not plan to assume their pension obligations. That is forcing the federal Pension Benefit Guaranty Corp. (PBGC) take over underfunded plans, and leaving retirees with the prospect of smaller pension payments. ${ }^{50}$ Among the companies:

- The Tribune Co., which publishes the Chicago Tribune, Los Angeles Times, Baltimore Sun, and five other large metro daily papers. The Tribune Co. is enmeshed in a legal battle that has hampered its ability to emerge from bankruptcy.

- Philadelphia Newspapers LLC, which publishes the Philadelphia Inquirer and the Philadelphia Daily News, filed for bankruptcy in February 2009. It was sold to a group of financial firms in April 2010 after a competitive auction, ${ }^{51}$ though the deadline for the sale was delayed until mid-September due to protracted negotiations with affected labor unions. Pension payments have been an issue in the dispute. ${ }^{52}$

- Sun-Times Media Group, which owns the Chicago Sun Times and suburban papers, filed for bankruptcy in March 2009. The company was acquired by Sun-

\footnotetext{
${ }^{47}$ Pew Research Center's Project for Excellence in Journalism, The State of the News Media 2009: An Annual Report on American Journalism. http://www.stateofthemedia.org/2009/index.htm.

${ }^{48}$ Securities and Exchange Commission. Form 10-Q filed by Lee Enterprises for the period ended March 29, 2009.

${ }^{49}$ Lee Enterprises, “Lee Enterprises reports Q3 earnings growth,” Press Release, July 20, 2010.

${ }^{50}$ Pension Benefit Guaranty Corporation, "PBGC Assumes Responsibility for Chicago Sun-Times Pension Plans," News Release, August 12, 2010.

${ }^{51}$ Christopher K. Hepp and Harold Brubaker, "Phila. Newspapers Sold to Lenders," Philadelphia Inquirer, April 28, 2010.

${ }^{52}$ Christopher K. Hepp, “Newspapers' sale deadline extended for 2 weeks,” Philadelphia Inquirer, August 31, 2010.
} 
Times Media Holdings, led by financier James Tyree, in October $2009 .{ }^{53}$ The PBGC in August 2010 assumed seven Sun-Times pension plans, covering nearly 2,360 workers. According to the PBGC, the plans were 53\% funded, with $\$ 55.8$ million in assets to cover $\$ 106.5$ million in benefit liabilities. ${ }^{54}$

- Star Tribune Holdings Co., which owns the Star Tribune of Minneapolis, filed for bankruptcy in January 2009. It emerged as a reorganized entity in September $2009 .^{55}$

- Journal-Register Co., which owns the New Haven Register, Trentonian and Daily Local News of West Chester, Pa., among other papers, filed for bankruptcy in February 2009. It emerged from bankruptcy, reorganized, in August $2009 .{ }^{56}$

- American Community Newspapers, which publishes the Stillwater (MN) Gazette and the Plano Star Courier, in addition to non-daily papers in four states, filed for bankruptcy in April 2009. The company emerged, reorganized, in June $2009 .^{57}$

- Creative Loafing, which publishes alternative newspapers including the Chicago Reader, Washington City Paper, and others, filed for bankruptcy in September 2008. The company was purchased by hedge fund Atalaya Capital Management at a bankruptcy auction in August 2009. ${ }^{58}$

- MediaNews Group Inc., the publisher of dozens of newspapers, including the Denver Post and San Jose Mercury News, filed for bankruptcy protection in January 2010. It emerged from bankruptcy in March 2010.

During 2010, newspaper companies reported improved, but mixed, earnings. Many major newspaper groups were profitable in the second quarter of $2010 .{ }^{60}$ However, a number of newspaper companies reported that print advertising revenues continued to decline during the period, even when compared to the low figures realized in the second quarter of 2009. The rate of decline slowed, however. While ad revenues at some major newspaper firms dropped by about $30 \%$ in the second quarter of 2009 compared to the previous year, they fell by less than $10 \%$ in the second quarter of $2010 .{ }^{61}$ Companies eked out earnings by cutting staff, raising the price of the newspaper, reducing circulation costs, and other strategies.

\footnotetext{
${ }^{53}$ Sun-Times Media Holdings, LLC, "Sun-Times Media Holdings LLC Announces Completion of Asset Transaction," Press Release, October 26, 2009, http://suntimesnewsgroup.com/releasedetail.cfm?ReleaseID=418749.

${ }^{54}$ Pension Benefit Guaranty Corporation, "PBGC Assumes Responsibility for Chicago Sun-Times Pension Plans," News Release, August 12, 2010.

${ }^{55}$ Star Tribune, "Star Tribune Emerges from Bankruptcy," September 28, 2009, http://startribunereorg.com/ pressrelease.pdf.

${ }^{56}$ Mark Fitzgerald, "CEO Paton: Journal Register Co. Q2 EBITDA Exceeds Goal, Profit-Sharing Could Kick In,” Editor \& Publisher, August 16, 2010.

${ }^{57}$ Editor \& Publisher, “ACN Emerges from Bankruptcy,” June 29, 2009.

${ }^{58}$ Jacqueline Palank, "Hedge Fund Taps Media Vets to Lead Creative Loafing," Wall Street Journal, September 2, 2009.

${ }^{59}$ Denver Business Journal, “MediaNews Group Parent Emerges From Chapter 11,” http://denver.bizjournals.com/ denver/stories/2010/03/15/daily69.html.

${ }^{60}$ The New York Times reported that its operating profit in the second quarter of 2010 doubled from the same period in 2009. Gannett Co. and the Washington Post Co. also reported improved earnings.

${ }^{61}$ Alan Mutter, “Q2 newspaper sales: less bad, but not good,” Reflections of a Newsosaur, August 2, 2010, (continued...)
} 
Smaller community papers generally have not experienced as severe a falloff in staff and revenues as big metro dailies, though they have taken large hits during the downturn. Ad revenue at community papers was down about $18.7 \%$ in the first quarter of 2009 , compared to an average decline of $28.8 \%$ at bigger papers. ${ }^{62}$ Newspaper analyst John Morton has estimated that about 1,000 smaller daily papers, with circulations under 50,000, remain profitable. Smaller papers are in a better financial position than large dailies for several reasons. Smaller papers are less dependent on classified ads, operate in less complex markets, and tend to be closer to their readers and advertisers than large dailies. ${ }^{63}$

The University of Missouri-Columbia, in an annual survey for community papers, found high brand loyalty, a preference for the print product, and less Internet competition than at big city papers. The most recent study looked at weekly community papers located in markets of 25,000 or less. ${ }^{64}$

\section{Alternative News Sources}

As traditional, print newspapers take a financial beating, new media sources are rising on the Internet, helped by low entry costs. Alternative sources of news and information are becoming available to a potentially vast audience via an increasing number of wired and wireless devices (including wireless netbooks, wireless phones, the iPhone and iPad and amazonkindle ${ }^{\circledR}$-style wireless e-readers). Emerging news organizations include a growing number of foundationfunded projects focused on investigative reporting, in-depth health policy news, and local reporting. Examples include ProPublica (ProPublica.org), Kaiser Health News, and Voice of San Diego ${ }^{65}$ GlobalPost is a for-profit enterprise, focused on international reporting, that relies on advertising, syndication to newspapers, and paid membership (http://www.globalpost.com).

But even the most promising startups do not have anywhere near the resources of major city daily papers, leading to concerns that important news will go uncovered. The decline of print newspapers also has other, indirect impacts. Many radio and television stations piggyback on reporting done by much larger newspaper staffs, both locally and nationally, and will be hardpressed to pick up the slack-especially as they impose their own cost-cutting in response to falling revenues. For example, the Dallas Morning News, which is owned by A. H. Belo, has more reporters in that city than the $\mathrm{ABC}, \mathrm{NBC}, \mathrm{CBS}$ and Fox television affiliates combined. ${ }^{66}$

\footnotetext{
(...continued)

http://newsosaur.blogspot.com/

${ }^{62}$ Lane, Nancy, “Community Papers Report First Quarter 2009 Results," Suburban Newspapers of America, June 2, 2009. http://www.suburban-news.org/News/SNANewsDetail.aspx?ID=100335.

${ }^{63}$ Morton, John, “Not Dead Yet,” American Journalism Review, June/July 2009 issue.

${ }^{64}$ Donald W. Reynolds Journalism Institute's Center for Advanced Social Research at the Missouri School of Journalism at the University of Missouri, "2008 Community Newspaper Study," with the National Newspaper Association.

${ }^{65}$ http://www.propublica.org/; http://www.kaiserhealthnews.org/; http://www.voiceofsandiego.org/.

${ }^{66}$ Testimony of James M. Moroney III, Committee on Commerce, Science and Transportation, Subcommittee on Communications, Technology and the Internet. Hearing on The Future of Journalism: Communications, Technology, and the Internet. May 6, 2009. http://commerce.senate.gov/public/index.cfm?FuseAction=Hearings. Testimony\& Hearing_ID=7f8df1a5-5504-4f4c-ba34-ba3dc3955c61\&Witness_ID=8406bab3-0f6f-422c-a805-c02103bb8ba5.
} 
So far, no one has come up with a workable strategy for garnering sufficient advertising or subscription revenues on the Internet, or through a hybrid print/online model, that would enable many troubled newspapers to continue at current staffing levels, or keep providing the same broad array of news, from recipes to foreign affairs to sports and local politics. Papers are experimenting, from charging "micropayments" for select content on the Internet to suggesting revenue-sharing with online search engines, such as Google, to cracking down on unauthorized reproduction of their content and creating their own spin-off websites and Web portals. Broadcast outlets are starting print and Web-based products in markets where newspapers are on the decline. ${ }^{67}$ Many newspapers are increasing subscription prices for their traditional print editions.

Table 2.Top 20 U.S. Daily Newspapers by Circulation

First six months of 2010 compared to same period in 2009

\begin{tabular}{|c|c|c|c|}
\hline Newspaper Name & As of $3 / 31 / 10$ & As of 3/31/09 & $\%$ Change \\
\hline Wall Street Journal & $2,092,523$ & $2,082,189$ & $0.50 \%$ \\
\hline USA Today & $1,826,622$ & $2,113,725$ & $-13.58 \%$ \\
\hline New York Times & 951,063 & $1,039,032$ & $-8.47 \%$ \\
\hline Los Angeles Times & 616,606 & 723,181 & $-14.74 \%$ \\
\hline Washington Post & 578,482 & 665,383 & $-13.06 \%$ \\
\hline New York Daily News & 535,059 & 602,859 & $-11.25 \%$ \\
\hline New York Post & 525,004 & 558,140 & $-5.94 \%$ \\
\hline San Jose Mercury News & 516,701 & $\mathrm{~N} / \mathrm{A}$ & $N / A$ \\
\hline Chicago Tribune & 452,145 & 501,202 & $-9.79 \%$ \\
\hline Houston Chronicle & 366,578 & 425,138 & $-13.77 \%$ \\
\hline Philadelphia Inquirer & 356,189 & $\mathrm{~N} / \mathrm{A}$ & N/A \\
\hline Arizona Republic & 351,207 & 389,701 & $-9.88 \%$ \\
\hline Newsday & 334,809 & 368,195 & $-9.07 \%$ \\
\hline Denver Post & 333,675 & $\mathrm{~N} / \mathrm{A}$ & N/A \\
\hline Minneapolis Star Tribune & 295,438 & 320,119 & $-7.71 \%$ \\
\hline St. Petersburg Times & 278,888 & 283,093 & $-1.49 \%$ \\
\hline Chicago Sun-Times & 268,803 & $3|2| 4 \mid$, & $-13.88 \%$ \\
\hline San Diego Union-Tribune & 249,630 & 261,253 & $-4.45 \%$ \\
\hline San Francisco Chronicle & 241,330 & 312,118 & $-22.68 \%$ \\
\hline Newark Star-Ledger & 236,017 & 287,082 & $-17.79 \%$ \\
\hline
\end{tabular}

Source: Audit Bureau of Circulations.

\footnotetext{
${ }^{67}$ Malone, Michael, “Stations Search for Gold in a Post-Newspaper Landscape,” Broadcasting \& Cable, May 2, 2009. http://www.broadcastingcable.com/article/

231044Cover_Story_Stations_Search_for_Gold_In_a_Post_Newspaper_Landscape.php.
} 
Typically, new business models are slowly introduced as old ones become less viable. But the current, deep recession, by cutting into newspaper earnings, has compressed the time period for developing new business plans and limited the amount of money newspapers have to devote to current operations, let alone craft sweeping initiatives.

\section{Rise of the Web}

For now, the key challenge for newspapers is to hold on to lucrative print readers, while finding ways to make more money from a growing online audience that generally reads the paper for free. Print circulation of daily papers fell by $13.5 \%$ from 2001 to 2008, and $17.3 \%$ for Sunday editions. ${ }^{68}$ Losses are mounting. Average daily newspaper print circulation (based on the top 602 newspapers by audience size) fell 8.7\% during the six-month period ending March 31, 2010, compared to the same period in 2009 (See Table 2) ${ }^{69}$ During the previous six-month period, circulation declined nearly $11 \%$ from the previous year.

Declining circulation numbers reflect, in part, a conscious effort by some papers to reduce printing and other costs by moving to online-only editions or shrinking their delivery area. The Detroit News and Detroit Free Press, which are combined in a joint operating agreement, cut daily delivery of the print newspapers to three days a week. ${ }^{70}$ Newspapers have their own ad campaign to promote the industry. ${ }^{71}$

As print circulation declines, online readership has surged - though it is difficult to give a precise figure, since estimates on online readership, developed through surveys and sampling techniques, vary widely. ${ }^{72}$ Audience measurement firm comScore pegged unique visitors to top newspaper groups (websites operated by newspaper companies) at 123 million in May 2010. (See Table 3).

Newspapers are attracting online readers from well beyond their local communities, including other cities and countries. Newspaper executives point to online readership as an endorsement of their product, saying public interest in news has increased, not diminished. But readership trends are complex, as habits and preferences evolve in response to the enormous array of information available on the Internet, television, and through devices such as hand-held readers and cell phones. Though readers want news, they do not necessarily want it from a traditional paper, and are using multiple sources. For example, there is just one newspaper in the top five news websites in 2009, as measured by Nielsen Online. ${ }^{73}$ The biggest news websites, in descending order, are Yahoo News, MSNBC Digital Network, AOL News, CNN.com, and NYTimes.com. MSNBC had

\footnotetext{
${ }^{68}$ Pew Research Center's Project for Excellence in Journalism, The State of the News Media 2009: An Annual Report on American Journalism. http://www.stateofthemedia.org/2009/index.htm.

${ }^{69}$ Audit Bureau of Circulations, April 27, 2009, http://abcas3.accessabc.com/ecirc/newstitlesearchus.asp; Saba, Jennifer, "New FAS-FAX Shows (More) Steep Circulation Losses," Editor \& Publisher, April 27, 2009.

${ }^{70}$ Press Release From Detroit Media Partnership, December 16, 2008. http://www.freep.com/article/20081216/ BUSINESS06/81216036/.

${ }^{71} \mathrm{http}: / /$ news.newspaperproject.org/.

${ }^{72}$ Lucas Graves, “Traffic Jam: We'll never agree about online audience size," Columbia Journalism Review, September/October 2010.

${ }^{73}$ Pew Project for Excellence in Journalism, The State of the News Media, 2010: Online, http://www.stateofthemedia.org/2010/online_nielsen.php\#online_top20sitesbysector.
} 
nearly twice the online audience of the New York Times. ${ }^{74}$ Among those sites, Yahoo and AOL News in the past have mainly aggregated news from other organizations, though they have recently started operations to increase their own original content.

Consumer demand and technology are changing the way news is read and offered. Most newspapers offer a general package of sports, entertainment, business, and national stories, with editors signaling the importance of the news by its placement in the physical paper. Today, websites like Google or Yahoo are mimicking the job of editors, by using sophisticated computer programs to automatically compile links to content from newspapers, wire services, blogs, and other sources from around the world. Other so-called aggregators run websites that mix links to newspapers' stories with some original content, and bloggers frequently mingle newspaper and other reporting with their own commentary and insights. Increasingly individual stories are displayed on the Web as discrete products, separate from a broader newspaper.

Table 3. Newspaper Website Readership

Newspaper website readership at top media companies

\begin{tabular}{lcc}
\hline Newspaper Website & Unique Views in May 2010 & Average Pages Per Visitor \\
\hline The New York Times Brand & $32,530,000$ & 22 \\
Tribune Newspapers & $24,753,000$ & 14 \\
Advance Internet (I) & $18,053,000$ & 18 \\
USA Today Sites & $16,771,000$ & 9 \\
Washington Post.com & $16,677,000$ & 11 \\
McClatchy Corporation & $13,987,000$ & 15 \\
MediaNews Group & $13,362,000$ & 11 \\
New York Daily News.com & $12,502,000$ & 10 \\
Hearst Newspapers & $12,017,000$ & 16 \\
Wall Street Journal Online(2) & $11,325,000$ & 10 \\
\hline
\end{tabular}

Source: comScore. Online traffic can fluctuate widely from month to month and can vary depending on the different firms' measurement techniques.

Note: (I) Advance Internet is a privately held company that oversees the Internet strategy for affiliates of Advance Publications, Inc., The company has developed branded sites for local newspapers including NJ.com, cleveland.com and OregonLive. (2) Wall Street Journal Online is a paid website.

About 22\% of readers who visited newspaper websites in March 2009 arrived indirectly, by first clicking onto online search engines like Google, with another big share arriving through the front page of Web portals like Yahoo or MSN, according to one analysis. A separate $22 \%$ came from traffic moving between media and news websites containing links to specific stories. ${ }^{75}$ Once readers arrive at newspaper websites, they spend less time there, on average, than print readers spend reading a traditional newspaper, though some studies show that time online has been

\footnotetext{
${ }^{74}$ Langeveld, Martin, “Online newspaper audience growth: Good news? Not really,” Nieman Journalism Lab, Harvard University, April 26, 2009. http://www.niemanlab.org/2009/04/online-newspaper-audience-growth-good-news-notreally/\#more-4442.

${ }^{75}$ Dougherty, Heather, "Online news aggregators-friend or foe?," Hitwise, April 8, 2009. http://weblogs.hitwise.com/ heather-dougherty/2009/04/online_news_aggregators_friend.html.
} 
increasing. Web readers spend an average of 53 minutes a week with newspapers-or just under eight minutes a day, according to a study by the Annenberg School of Communication at the University of Southern California. The study also found, however, that $22 \%$ of readers had recently dropped a paid print newspaper or magazine subscription because they could get the paper free online. ${ }^{76}$

By contrast, Northwestern University researchers found that consumers who read print newspapers in 2008 averaged 27 minutes with the paper on weekdays and 57 minutes on Sundays. Readers peruse their print newspaper about five days a week, completing $60 \%$ of the newspaper on a typical weekday and $62 \%$ on Sunday. ${ }^{77}$

Younger consumers have traditionally had lower readership rates than older consumers, a trend that is continuing and possibly accelerating, even though young Americans are spending more time online. Just $5 \%$ of teens and $9 \%$ of young adults called themselves heavy users of newspapers in a 2007 survey. At the same time, only $8 \%$ of teens and $13 \%$ of young adults reported themselves as heavy consumers of Internet-based news-while the majority of both age groups termed themselves non-users of news. ${ }^{78}$ But older Americans may be less loyal readers than in the past. The Pew Research Center, in a survey of 2008 reading patterns, found $53 \%$ of those in the Silent/Greatest Generation age bracket (born before 1946) reported reading a newspaper the previous day. A decade earlier, the share was $65 \%{ }^{79}$

\section{Interdependence}

While future growth is clearly online, there is still a huge interdependence between traditional print, with its tens of millions of readers, and emerging Internet products. Many so-called new media ventures rely partly on print advertising for their revenues. The political news publication Politico makes about $50 \%$ of its money from ads in its free print newspaper (published several times a week), even though it has more than 3 million online readers. ${ }^{80}$ Web aggregators such as the Huffington Post or Drudge Report rely on links to information and content from traditional print newspapers. The combination of a print and Web presence can give a paper a potent reach. In 81 local markets studied by Scarborough Research, $75 \%$ of adults read the paper weekly in print or online. ${ }^{81}$

\footnotetext{
${ }^{76}$ University of Southern California, Annenberg School of Communication, Annual Internet Survey by the Center for the Digital Future finds large increases in use of online newspapers, April 29, 2009. http://www.digitalcenter.org/pdf/ 2009_Digital_Future_Project_Release_Highlights.pdf. Other studies peg online readership at much lower levels. Data by Nielsen Online for the National Newspaper Assn. show the more than 70 million unique online readers in April visited websites an average of eight times and spent 43 minutes online per month. http://www.naa.org/ TrendsandNumbers/Newspaper-Websites.aspx.

${ }^{77}$ Peer, Limor, Mary Nesbitt and Bob LeBailly, "Reader Behavior Scores, local daily newspapers, 2008," Northwestern University, July 2008. http://www.readership.org/consumers/rbs/data/rbs2008.pdf.

${ }^{78}$ Harvard University, Kennedy School of Government, Young People and News, Joan Shorenstein Center on the Press, Politics and Public Policy, July 2007, p 11.

${ }^{79}$ Pew Research Center for the People \& the Press, "Newspapers Face a Challenging Calculus," February 26, 2009.

${ }^{80}$ Information comes from Politico Editor-in-Chief John Harris in a June 27 speech to the Individuated News Conference, held at the Washington Times, Washington, DC.

${ }^{81}$ Scarborough Research, "Rochester, Cleveland and Buffalo are Tops for Print/Online Newspaper Readers," March 25, 2009. http://www.scarborough.com/press_releases/INA\%20FINAL\%203.25.pdf.
} 
For a time it appeared the traditional advertising model might work for online news, as Internet ad revenues started to take off earlier this decade. Those trends have begun to reverse. Combined newspaper print and online ad revenue was $\$ 27.6$ billion in 2009, down about $44 \%$ from the 2005 level of $\$ 49.4$ billion. $^{82}$ The 2009 figure includes $\$ 24.8$ billion from print and $\$ 2.7$ billion from online advertising (which was down $11.8 \%$ from 2008).

There are a host of reasons why newspapers' Internet ad revenues have not been more robust, including the fact that the industry arguably was somewhat slow to embrace the technology. In 1995, a group of nine large media companies formed the New Century Network, with the idea of pooling resources and competing with online companies. The effort foundered as the companies disagreed on strategy, and was shut down in $1998 .{ }^{83}$ Individual companies formed partnerships with online companies like Amazon.com. The New York Times in 2005 announced TimesSelect, charging readers for access to prominent editorialists and other content. It ended the venture in 2007. With $\$ 10$ million in revenues, the Times believed that TimesSelect was a success, but decided that "by opening millions of pages to search engines, that traffic growth will continue and with it, ad revenue growth." ${ }^{, 84}$ The Times has announced that it will begin a new, modified payper-view system for some of its content in 2011.

Figure 2. Newspaper Advertising Revenues

Daily Newspaper Ad Revenues Have Fallen Sharply

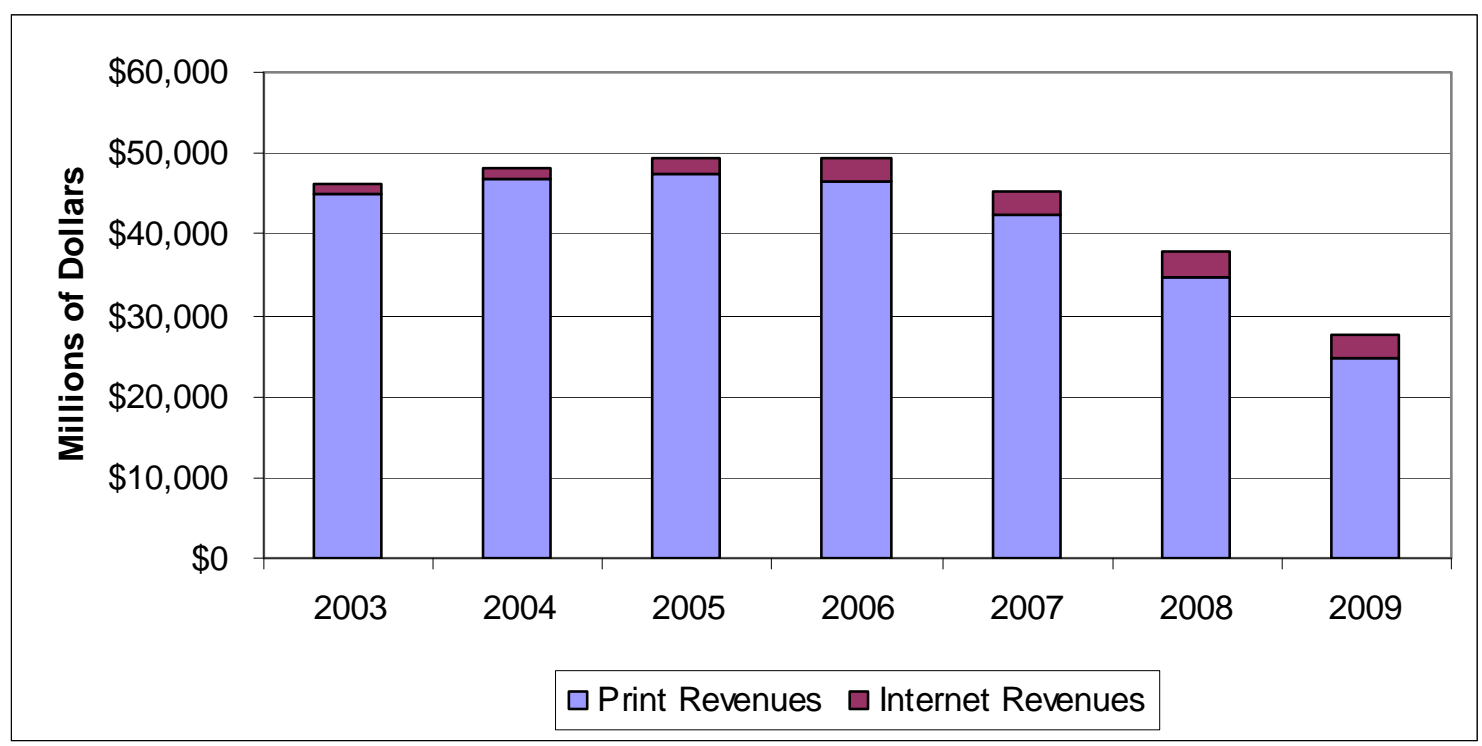

Source: Newspaper Association of America.

\footnotetext{
${ }^{82}$ Business Analysis and Research, Newspaper Association of America. http://www.naa.org/TrendsandNumbers/ Advertising-Expenditures.aspx (viewed May 25, 2009).

${ }^{83}$ Dugan, Ianthe Jeanne, "New-Media Meltdown at New Century,” Business Week, March 23, 1998. http://74.125.47.132/search?q=cache:9y1hivSDmeQJ:www.businessweek.com/archives/1998/ b3570103.arc.htm+new+media+meltdown+at+new+century+business+week\&cd=2\&hl=en\&ct=clnk\&gl=us

${ }^{84}$ Kramer, Staci D., "New York Times to Close TimesSelect Effective Midnight Tuesday; Will Open Last 20 Years of Archives," paid.Content.org: The Economics of Content. September 17, 2007. http://www.paidcontent.org/entry/419new-york-times-to-close-timesselect-effective-wednesday/.
} 
While newspapers were slow to seize the online market, Internet companies like Google, Yahoo and others have successfully captured tens of billions of advertising dollars. Some media executives argue that Internet companies that offer advertising on their portals next to news from other publications, or via search engines that provide readers with headlines and a few lines of copy from newspaper stories, are unfairly making billions of dollars in advertising revenues at the expense of newspapers. Internet firms counter that their models fall within standard copyright law, and provide an essential service to newspapers since the links on their websites direct millions of readers to newspaper home pages. They also note that newspapers can easily block content from other sources that aggregate news through simple computer code. ${ }^{85}$ Many newspapers themselves aggregate copy from multiple sources, with specialized online newspaper content by bloggers and columnists that frequently provide links to other media and non-media products. ${ }^{86}$

A number of websites go beyond providing a snippet of news articles to running entire stories from newspapers, without compensation. Media experts suggest this could be a fertile area for newspapers to garner more revenues. Services such as Attributor.com have created computer programs to help publishers track how their content is being used ${ }^{87}$ The Fair Syndication Consortium, which includes 1,500 publishers, including many newspaper companies, in late 2009 released data indicating that, from October 15, 2009, to November 15, 2009, more than 75,000 websites used at least one newspaper article online without permission. ${ }^{8}$

Some media experts say newspapers have not done enough to engage with readers, who want more control over the news they read. Major newspapers have had online websites for more than a decade, but initially created online versions of their print product that in retrospect were too static for the interactive Web. Most have elected not to charge readers for their online product, on the premise that doing so tends to reduce audience size and discourage advertisers. There are some notable exceptions to the model: The Wall Street Journal provides general access to only part of its website, and has more than a million paying online subscribers and provides its newspaper subscribers with access to its online subscription site. The Associated Press, a nonprofit cooperative of more than 1,400 newspapers, has contracted to sell full stories to Internet firms, including America Online, Google, and Yahoo.

The number of newspaper websites allowing consumer comment, streaming video, and other interactive features has been rising. At the same time, the number of newspapers requiring readers simply to register to enter their websites—-submitting basic age and geographic data-has declined as the industry has moved toward an increasingly open platform. ${ }^{89}$

Even if open access does lure more readers to websites, higher readership alone may not solve the problem. Online advertisements often sell for just a fraction of the price of print ads. A quarterpage ad in a print newspaper generally costs about $\$ 10$ per 1,000 consumers. On the Internet, a

\footnotetext{
${ }^{85}$ Testimony of Marissa Mayer, Google Vice President, Search Products and User Experience, Senate Commerce, Science and Transportation Subcommittee on Communications, Technology and the Internet, May 6, 2009.

${ }^{86}$ Ibid.

${ }^{87} \mathrm{http}: / /$ www.attributor.com/about_us.php.

${ }^{88}$ Fair Syndication Consortium, “U.S. Newspaper Content Reuse Study,” December 1, 2009, http://www.fairsyndication.org/blog/2009/u-s-newspaper-content-reuse-study/\#comments.

${ }^{89}$ The Bivings Group, “The Use of the Internet by America's Newspapers," December 18, 2008. http://www.bivingsreport.com/2008/the-use-of-the-internet-by-americas-largest-newspapers-2008-edition/.
} 
"skyscraper ad" up the side of the screen, or a large banner ad across the top of a screen, can run $\$ 5$ to $\$ 8$ per 1,000 viewers, and some national display ads cost less than $\$ 1$ per $1,000 .{ }^{90}$ Ad rates are also declining as the number of websites competing for consumers' attention proliferates, the economy worsens, and companies become more sophisticated about tracking consumers who view or click on an ad. There are signs that publishers were faring better in 2009. PubMatic, a private firm that works with 5,500 online publishers, estimates display ad prices dropped nearly $50 \%$ from the end of 2007 to the end of $2008 .{ }^{91}$ PubMatic says that ad prices at the most prominent online publications began to rebound in 2009.

Some publishers have had success getting higher prices for online ad rates, including a group of about 800 newspapers that have joined in an alliance with Yahoo, which allows cross-selling of ads on their websites and on Yahoo and more ability to target ads based on consumer data gleaned through Web visits. ${ }^{92}$

In another challenge to the traditional ad-based model, U.S. businesses are altering advertising strategy by developing their own specialized websites as marketing tools to drive traffic to their stores or products. Consumers now have access to online circulars, such as Coupons.com, RetailMeNot.com and Coupon Cabin (couponcabin.com) ${ }^{93}$ Regal Entertainment Group, the top U.S. movie chain, told investors in 2009 it had cut its advertising from $\$ 13,000$ per screen in 1999 to $\$ 3,000$ a screen. Movie customers are getting more movie and show-time information online, with newspapers now a second or third choice. ${ }^{94}$

IBM Global Business Services projects traditional media such as newspapers, radio, and television will have $32 \%$ of the advertising market in 2012, down from $47 \%$ in $2002 .{ }^{95}$ Advertisers are turning to strategies like product placement in films and television, and are trying to tap into social networks such as Facebook. Companies are using online data to closely track specific shoppers and tailor products to their needs, raising potential privacy issues. ${ }^{96}$

\section{Searching for New Business Models}

The Harvard Business School has developed a case study, entitled The Newspaper Industry in Crisis, as a teaching tool "to help students to understand the dynamics of radical industry change and foster a discussion around potentially viable business models on the internet." The premise of the study is that the newspaper's $19^{\text {th }}$ century business model has been turned upside down by the near instantaneous dissemination of news through multiple channels. The rapidity of industry

\footnotetext{
${ }^{90}$ Borrell, Gordon, CEO of Borrell Associates, a Williamsburg, Va.-based advertising consulting firm.

${ }^{91}$ PubMatic, "The Q4 2008 AdPrice Index," January 2009. PubMatic, "Premium Publisher Ad Price Index: 2009 Year in Review," http://www.pubmatic.com/wp-content/uploads/2010/01/PubMatic_Ad_Price_Index_Jan_2010.pdf.

${ }^{92}$ Helft, Miguel, Yahoo Teams with Newspapers to Sell Ads, New York Times, February 27, 2009. http://www.nytimes.com/2009/02/28/technology/internet/28yahoo.html.

${ }^{93}$ The Nielsen Co., "The Global Online Media Landscape, Identifying Opportunities in a Challenging Market,” p. 17. http://nielsen-online.com/emc/0904_report/nielsen-online-global-lanscapefinal1.pdf.

${ }^{94}$ Regal Entertainment Investor Day, May 12, 2009. See Reuters Mediafile, "Regal: Movie goers use Web for info, not Newspapers," May 13, 2009. http://blogs.reuters.com/mediafile/2009/05/13/regal-movie-goers-use-web-for-info-notnewspapers/.

${ }^{95}$ Berman, Saul, Bill Battino and Karen Feldman, "Beyond Advertising: Choosing a strategic path to the digital consumer," IBM Global Business Services, p. 6.

${ }^{96}$ CRS Report RL34693, Privacy Law and Online Advertising, by Kathleen Ann Ruane.
} 
change has forced newspaper executives to make major business decisions with only limited data and real-world experience. ${ }^{97}$

Newspapers are increasingly talking about setting up so-called pay walls around parts of their product. Some experts predict media companies could end up in a net loss position, however, even if they set low online subscription or individual payment fees. ${ }^{98}$ James Moroney, publisher and CEO of the Dallas Morning News, speaking on behalf of newspaper publishers, asked a Senate Commerce subcommittee in May 2009 to give newspapers a limited antitrust exemption so they could "jointly experiment with innovative content distribution and cost-saving arrangements. ${ }^{\prime 99}$ Moroney argued that newspapers must act as a group to impose new payments for online content if their efforts are to be successful. Without joint action, readers will simply turn to other online information.

But publishers are starting to rework their online strategy even without congressional action. MediaNews Group, which operates 54 daily papers in 11 states, has announced that it will stop providing unfettered access to its websites, saying the policy was "an injustice" to print subscribers and created the impression that the content had no value. The company plans to begin charging for select content, create more separation between its online and print sites, and create a new "local utility site" focused on younger readers with entertainment, shopping, and other services. ${ }^{100}$

Publisher Steven Brill and other media investors have created a venture called Journalism Online, to create a password-protected website where consumers can buy annual or monthly subscriptions, day passes, or single articles from major publishers. The company would also negotiate licensing and royalty fees with search engines and other providers. ${ }^{101}$ A consortium of newspapers working with Yahoo to improve ad targeting is seeing some early success. ${ }^{102}$

Consumers who buy Amazon.com Kindle e-readers, Barnes \& Noble Nook e-readers, or any of a growing number of similar electronic devices can purchase monthly subscriptions to the New York Times, Washington Post, Wall Street Journal, and numerous other major newspapers at rates that can be hundreds of dollars below the cost of a print subscription. ${ }^{103}$ Newspapers and other media organizations have developed a multitude of media applications for Apple's iPad and iPhone. Some, including USA Today, are free, while others are fee-based.

\footnotetext{
${ }^{97}$ Collis, David J., Peter Olson, Mary Furey, The Newspaper Industry in Crisis, Harvard Business School, Case Study \# N2-709-463, March 11, 2009.

${ }^{98}$ Langeveld, Martin, "Paying for online news, Sorry but the math just doesn't work," Nieman Journalism Lab, Harvard University, April 3, 2009; Media Café, Mignon Media, "Charging for Online Content? New Updated Figures for newspapers with a circulation of 50K." http://mediacafe.blogspot.com/.

${ }^{99}$ Testimony of James M. Moroney III, Senate Committee on Commerce, Science and Transportation, Subcommittee on Communications, Technology and the Internet. Hearing on The Future of Journalism: Communications, Technology, and the Internet. May 6, 2009. http://commerce.senate.gov/public/index.cfm?FuseAction= Hearings.Testimony\&Hearing_ID=7f8df1a5-5504-4f4c-ba34-ba3dc3955c61\&Witness_ID=8406bab3-0f6f-422c-a805c02103bb8ba5.

${ }^{100}$ MediaNews memo, May 8, 2009. http://www.poynter.org/column.asp?id=45\&aid=163508.

101 "Media Leaders Form Journalism Online, LLC," press release April 14, 2009. http://www.journalismonline.com/.

102 Ives, Nat, "Some Newspapers Booking Local Ads, Thanks to Yahoo,” Advertising Age, May 21, 2009.

${ }^{103}$ See http://www.amazon.com/Kindle-Newspapers/b/ref=sa_menu_knews3?ie=UTF8\&node=1263068011\&pf_rd_p= 328655101\&pf_rd_s=left-nav-1\&pf_rd_t=101\&pf_rd_i=507846\&pf_rd_m=ATVPDKIKX0DER\&pf_rd_r=

1JJBXJHBAD4E07CYSZDS. See http://www.barnesandnoble.com/ebooks/enewspapers.asp.
} 
In a small number of cases, papers are turning to Web-only production. Researchers at the City University of London analyzed a 2007 decision by the Finnish financial daily Taloussanomat to become the first all-digital newspaper in Europe. The paper ended subscriptions and offered readers access through the Web, mobile phones, and e-mail. The newspaper reduced costs more than $50 \%$ by eliminating print and delivery cost, and saved additional money by reducing staff. Revenues plunged by $75 \%$, however, from the loss of print ads and circulation dollars. Online advertising did not increase as expected. "Although Taloussanomat's visitor numbers have risen following their decision to go online-only, the rise has been faltering and markedly less than at some other online newspapers that retained a print edition." 104

The authors say Taloussanomat's strategy could work for some troubled papers, but operating losses need to be high to justify such a dramatic change. In the United States, there are indications that Web readership has fallen off since the Seattle Post Intelligencer moved to a Web-only publication.

The Christian Science Monitor was the first national newspaper to move to a Web-only daily edition. The paper also offers readers the chance to subscribe to a weekly print and daily e-mail edition. Christian Science Monitor Editor John Yemma said the CSMonitor.com in September 2010 had 5 million-plus monthly unique visitors, with monthly page views of 17 million-three times the level of a year ago. Weekly print circulation was 70,000. The paper also circulates via free newsletters, an e-mail Daily News Briefing PDF document, and e-readers such as the Amazon.com Kindle and the Barnes \& Noble Nook. ${ }^{105}$

Some newspaper publishers are trying to diversify their operations to generate additional revenue streams. Often, however, the companies have branched into other media and Internet ventures that are also taking a financial hit during the downturn. Gannett, in addition to being the nation's largest newspaper chain, owns television stations and is investing in digital products, such as PointRoll, an Internet ad services business. Gannett earned \$586 million from digital operations in 2009, out of overall revenues of $\$ 5.6$ billion. Gannett publishing revenues declined $23 \%$ for the year, compared to 2008, while digital revenues were down a smaller $15 \%{ }^{106}$ The Washington Post Co., which owns the Washington Post and Newsweek, derives the bulk of its revenues from its Kaplan Inc. educational division and its Cable One cable division. ${ }^{107}$

\section{Nonprofits}

One idea garnering significant attention is organizing or reorganizing newspapers as nonprofit entities, thus shielding them from taxes on certain income and allowing businesses and individuals to deduct the cost of subscriptions or to make tax-deductible contributions. Senator Benjamin Cardin during the $111^{\text {th }}$ Congress proposed S. 673, to clarify questions about tax deductibility, allowable advertising, and other issues, while making it clear that newspapers organized as nonprofits would not be allowed to make political endorsements.

\footnotetext{
${ }^{104}$ Thurman, Neal and Merja Myllylahti, "Taking the Paper out of News: A case study of Taloussanomat, Europe's first online-only newspaper," Graduate School of Journalism, City University, London, 2009.

105 Interview with John Yemma, September 8, 2010.

${ }^{106}$ Gannett Co., 2009 Annual Report, p. 28, http://www.gannett.com/GCI2009AnnualReport.pdf.

${ }^{107}$ Standard \& Poor's Stock Report, Washington Post Co., May 23, 2009. Washington Post, "The Washington Post Reports Second Quarter Earnings,” Press Release, August 6, 2010.
} 
Newspaper publishers and union representatives have discussed similar proposals that would let newspapers organize as low-profit limited liability corporations, known as L3Cs, that combine aspects of a nonprofit and for-profit business, including a cap on profits. The L3Cs are allowed in some states. ${ }^{108}$

There are already a number of high profile, nonprofit news organizations operating in the United States, including the Christian Science Monitor. ${ }^{109}$ Times Publishing Co., which is owned by the nonprofit Poynter Institute for Media Studies, an educational institution. The Poynter Institute publishes the St. Petersburg Times; Tampa Bay Times, a free daily; and Florida Trend, a business magazine. After-tax earnings are put back into the business and into the Poynter Institute, a nonprofit educational institution. ${ }^{10}$

Publisher Nelson Poynter created the nonprofit structure in the 1970s in part to shield the St. Petersburg Times from outside corporate raiders and ensure its editorial independence. That mission appears to have succeeded, but the model is not a guarantee of financial security in a changing market environment. Just as other educational institutions have seen their endowments decline, the Poynter Institute is facing financial pressures. The severe housing slump in Florida has hurt newspaper earnings. The Poynter Institute in 2009 sold two of its publications, Congressional Quarterly and Governing magazine. ${ }^{111}$

The nonprofit model is gaining ground in some areas such as investigative journalism. Organizations including the Center for Investigative Reporting, the Center for Public Integrity, and Investigative Reporters and Editors have worked for years to expand and strengthen investigative reporting through their own projects and by training journalists. ProPublica, which started operations in 2008, has a staff of more than 30 reporters pursuing investigative stories, sometimes in conjunction with other media organizations. The field is rapidly expanding, often in affiliation with colleges and universities, many with their own schools of journalism. There are investigative reporting centers at Columbia University, Brandeis University, American University, and Boston University. Another center is supported by the University of Wisconsin. Efforts are under way to create centers at the University of Washington and at the University of Colorado. ${ }^{112}$ The Huffington Post, in partnership with Atlantic Philanthropies, created an investigative reporting project, with an initial $\$ 1.75$ million budget.

Additional nonprofit models include the Pulitzer Center On Crisis Reporting (http://www.pulitzercenter.org), which focuses on training and reporting of international news. MinnPost (http://www.minnpost.com) is a nonprofit news website, as is voice of san diego.org.

\footnotetext{
${ }^{108}$ Pickard, Victor, Josh Stearns \& Craig Aaron, Saving the News: Toward a National Journalism Strategy. Free Press, 2009. http://www.freepress.net/files/saving_the_news.pdf.

${ }^{109}$ The St. Petersburg Times won two Pulitzer Prizes in 2009, one for national reporting and the other for feature writing. Columbia University News, Columbia University Announces $93^{\text {rd }}$ Annual Pulitzer Prizes In Journalism, Letters, Drama and Music, April 20, 2009.

${ }^{110} \mathrm{http} / / /$ www.hoovers.com/the-poynter-institute/_ID_107699_/free-co-factsheet.xhtml; "The Poynter Institute, What We Do," http://www.poynter.org/content/content_view.asp?id=8090.

${ }^{111}$ James Thorner, “Times Publishing Co. agrees to sell Governing magazine to e.Republic," St. Petersburg Times, November 21, 2009, http://www.tampabay.com/news/business/realestate/times-publishing-co-agrees-to-sell-governingmagazine-to-erepublic/1053155.

${ }^{112}$ Houston, Brant, Knight Chair in Investigative and Enterprise Reporting, University of Illinois, "The First Draft: Emerging Models for Regional and State Non-Profit Investigative Journalism Centers," Duke Conference on Nonprofit Media, May 4-5, 2009.
} 


\section{Public Policy Issues}

Some observers suggest that escalating problems in the newspaper industry could have broad social and civic implications, as fewer reporters monitor increasingly complex decisions by government and business. A Princeton University analysis published by the National Bureau of Economic Research found, for example, that the year after the Cincinnati Post closed in 2007, fewer candidates in the suburbs that had previously been covered by the paper ran for municipal office, incumbents became more likely to win, and voter turnout fell. ${ }^{113}$

Alberto Ibarguen, president of the John S. and James L. Knight Foundation, worries that many Americans will have less access to news, including those in areas not served by high-speed broadband, the poor, and older readers who are less Web-savvy. News could become more bifurcated, with significantly less access for many citizens. The Web offers abundant information on national and international issues. It is also a place where Americans are splintering into selfdefined communities - connected through social networks or shared interests like travel or sports-whereas mainstream newspapers serve civic societies defined by geographic and political boundaries. ${ }^{114}$ "We already live in an era where it is more likely that a high school student can more easily access information about swine flu or the crisis in Darfur than corruption in city government or decisions about education in his town," Ibarguen told a Senate committee in May.

Other observers see the decline of newspapers as part of a natural, even necessary, transition for an industry that is variously described as having become too liberal, too corporate, too smug, or too ineffectual and generally in need of a good shaking up. In a market-based economy, some argue, the best approach is to let new models arise without government direction or interference. In a recent survey, only $43 \%$ of respondents said losing their local newspaper would hurt civic life in their community "a lot." 115

Mark Potts, a former Washington Post journalist who is now a media consultant and analyst, in a recent speech and subsequent Web posting, questioned the suggestion that communities will be bereft of options if major newspapers such as the Baltimore Sun cease operation. At a symposium in Baltimore he laid out a list of alternative weekly papers, business publications, websites and blogs that have already arisen to serve local readers. ${ }^{116}$

\section{Congressional Action}

Congress during the $111^{\text {th }}$ Congress began discussing broader issues arising from the transformation of the newspaper industry, but the debate did not go beyond the hearing stage. The House Judiciary Subcommittee on Courts and Competition Policy in April 2009 held a hearing on

\footnotetext{
${ }^{113}$ Schulhofer-Wohl, Sam and Miguel Garrido, "Do Newspapers Matter? Evidence from the Closure of the Cincinnati Post,” National Bureau of Economic Research, Working Paper 14817, March 2009. http://www.nber.org/papers/ w14817.pdf.

${ }^{114}$ Testimony of Alberto Ibarguen, President, John S. and James L. Knight Foundation, Senate Commerce, Science and Transportation Subcommittee on Communications, Technology, and the Internet, May 6, 2009.

115 "Stop the Presses? Many Americans Wouldn't Care a Lot if Local Papers Folded," The Pew Research Center for the People \& the Press, March 12, 2009.

${ }^{116}$ Potts, Mark, “Choices in Charm City,” Recovering Journalist, June 3, 2009. http://recoveringjournalist.typepad.com/ recovering_journalist/2009/06/choices-in-charm-city-1.html.
} 
the possibility of changing antitrust law to allow more collaboration and mergers in the newspaper industry. The Senate Commerce Subcommittee on Communications, Technology, and the Internet held a general hearing on the issue in May 2008. The Joint Economic Committee held a hearing on the state of the news industry in September 2009. ${ }^{117}$

The FTC in June 2010 completed a series of three workshops on the state of the news media. As part of the process, FTC staff compiled a discussion draft ${ }^{118}$ of suggestions from industry analysts and officials who participated in the process. The suggestions included expanding copyright protection for news, creating a national fund for local news to be funded from fees on telecom users, radio and television broadcast licensees, or Internet service providers; and imposing other taxes on consumers and businesses to subsidize journalism. FTC Chairman Jon Liebowitz opened the final roundtable in June 2010 by emphasizing that the FTC had not endorsed the discussion draft and stating that "taxing anyone to subsidize journalism is just a non-starter. In addition, as a competition agency, we are pretty allergic to antitrust exemptions, as well as to changes to expand copyright law."119

Just as there is no one business model that will return newspapers to the recent era of double-digit profitability, there does not appear to be any one legislative proposal that will stabilize the newspaper industry. The issue is further complicated by the fact that government involvement in the press raises potential conflicts of interest. Reporters and editorialists cover, and often write stories about, the legislators who are now being asked for help. Elected officials depend on newspapers for political endorsements and to communicate with their constituents.

\section{Industry Proposals}

Newspaper publishers in May 2009, among other things, asked the Senate to temporarily relax antitrust law to allow them to work together to set a new pricing policy for the Internet and to change tax law to allow media companies to write off past losses. ${ }^{120}$

Relaxing federal antitrust law to allow more newspaper mergers or to let newspaper publishers collaborate on Internet pricing policy could help bring new investment into the industry and create economies of scale. But the Newspaper Guild, one of the main unions in the newspaper industry, argues that newspaper chains have used mergers to undermine existing contracts. ${ }^{121}$ The policy could put startups at a disadvantage. The Justice Department at a House Judiciary subcommittee hearing was cool to expanded antitrust exemptions, saying current antitrust law is

\footnotetext{
${ }^{117}$ Joint Economic Committee, "The Future of Newspapers: The Impact on the Economy and Democracy," September 24, 2009, http://jec.senate.gov/public/index.cfm?p=Hearings\&ContentRecord_id=ce03ce4d-5056-8059-76f28b02fccb18e3\&ContentType_id=14f995b9-dfa5-407a-9d35-56cc7152a7ed\&Group_id=6d8935b0-4db8-4fc0-991e$3613943 \mathrm{~b} 7 \mathrm{e} 4 \mathrm{f} \&$ MonthDisplay=9\&YearDisplay=2009.

${ }^{118}$ Federal Trade Commission, Potential Policy Recommendations to Support the Reinvention of Journalism, http://www.ftc.gov/opp/workshops/news/jun15/docs/new-staff-discussion.pdf.

${ }^{119}$ Federal Trade Commission, “From Town Criers to Bloggers: How Will Journalism Survive the Internet Age?” June 15, 2010, http:/www.ftc.gov/opp/workshops/news/jun15/100615transcript.pdf.

${ }^{120}$ Testimony of James M. Moroney III, Committee on Commerce, Science and Transportation, Subcommittee on Communications, Technology and the Internet. Hearing on The Future of Journalism: Communications, Technology, and the Internet. May 6, 2009. http://commerce.senate.gov/public/index.cfm?FuseAction=Hearings.Testimony\& Hearing_ID=7f8df1a5-5504-4f4c-ba34-ba3dc3955c61\&Witness_ID=8406bab3-0f6f-422c-a805-c02103bb8ba5.

${ }^{121}$ Testimony by Newspaper Guild President Bernie Lunzer to the House Judiciary Committee, April 17, 2009.
} 
flexible enough to meet the needs of the changing media marketplace. ${ }^{122}$ Media companies are already announcing plans to move ahead with efforts to impose subscription or other pay rules for online content, in the absence of congressional action. ${ }^{123}$

Another potential avenue involves the fair use doctrine of copyright law. Some publishers say Internet aggregators or search engines are profiting unfairly selling advertising via Internet search functions that display several lines or headlines of original newspaper stories. ${ }^{124}$ Internet firms say their policies provide a major benefit to newspapers by directing millions of readers to their websites when they click on the displayed links. Newspapers have the ability to block so-called aggregators from posting links to their copy, and can require readers to register or subscribe to access their websites. A number of newspapers are themselves aggregators, with in-house bloggers or reporters who post links to other newspaper stories.

Even if newspapers do find a way to generate significantly higher online advertising returns, there are questions about whether Web-based revenues will be sufficient to support newspapers of the current size and scope. ${ }^{125}$

\section{Supporting the General Practice of Journalism}

Some media experts have suggested that the best approach is arms-length federal involvement, where Congress provides federal funding to support the general practice of news gathering, rather than supporting specific newspapers. Such proposals include helping newspapers convert to employee-owned or nonprofit entities, increasing public funding for existing institutions like the Corporation for Public Broadcasting, creating a public trust to support reporting, and bolstering journalism programs affiliated with educational institutions. ${ }^{126}$

Former Washington Post managing editor Steve Coll, now president of the New America Foundation, is among those suggesting that Congress support journalism by increasing funding for the Corporation for Public Broadcasting or the National Endowment for the Humanities. ${ }^{127}$ Free Press, a nonprofit organization aimed at promoting citizen participation in journalism, has suggested a research and development fund for innovation in journalism. ${ }^{128}$ Other proposals include creating a jobs-for-journalists program, instituting a prepackaged bankruptcy structure making it easier for papers to reorganize, ${ }^{129}$ and ending efforts to overturn a 2003 Federal

\footnotetext{
${ }^{122}$ Statement of Carl Shapiro, Deputy Assistant Attorney General for Economics, Antitrust Division, Department of Justice, House Justice Subcommittee on Courts and Competition Policy, April 21, 2009.

${ }^{123}$ Testimony of Marissa Mayer, Google Vice President, Search Products and User Experience, Senate Commerce, Science, and Transportation Subcommittee on Communications, Technology, and the Internet, May 6, 2009.

${ }^{124}$ Testimony of James M. Moroney III, Committee on Commerce, Science, and Transportation, Subcommittee on Communications, Technology, and the Internet. Hearing on The Future of Journalism: Communications, Technology, and the Internet. May 6, 2009.

${ }^{125}$ Collis, David J., Peter Olson, Mary Furey, The Newspaper Industry in Crisis, Harvard Business School, Case Study \# N2-709-463, March 11, 2009.

${ }^{126}$ Remarks of Acting FCC Chairman Michael J. Copps, Free Press Summit: Changing Media, Washington, DC May 14, 2009. http://www.fcc.gov.

${ }^{127}$ Testimony of Steve Coll, Committee on Commerce, Science, and Transportation, May 6, 2009.

${ }^{128}$ Pickard, Victor, Josh Stearns and Craig Aaron, Saving The News: Toward a National Journalism Strategy, Free Press, May 2009. http://www.freepress.net/files/saving_the_news.pdf.

${ }^{129}$ Ibid.
} 
Communications Commission (FCC) decision allowing cross-ownership of broadcast and print outlets in the same market. ${ }^{130}$ Another option could be to expand broadband access and increase training and technology literacy programs to ensure that all consumers have access to Internet news. $^{131}$

U.S. public financing has been controversial in the past, however. Republican lawmakers in the mid-1990s, for example, tried to eliminate funding for the Corporation for Public Broadcasting, citing its perceived liberal bias. The issue flared up again in the 2005 appropriations process. ${ }^{132}$

At the state level, the Washington legislature approved a temporary, 40\% state tax break for the news industry. ${ }^{133}$ New York Mayor Michael Bloomberg in July 2009 announced initiatives to encourage new media companies to locate in the city. ${ }^{134}$ Internationally, France has announced it will provide free, one-year newspaper subscriptions to teenagers on their $18^{\text {th }}$ birthday, increase French government print advertising, and boost financial support for newspaper deliveries. ${ }^{135}$ More narrowly, the Senate Press Gallery has had to review its definition of what constitutes a reporter or news agency, in response to requests from foundation-supported and online organizations that seek full press credentials, needed to cover much of official Washington. ${ }^{136}$

"While we may have once hoped that we could merely shift our operations online and continue operating as usual, the comparably much smaller revenue generated from Internet advertising has shown that we must continue to look for another answer. We can't wait to see if advertising revenue comes back after the recession is over, as much of it won't," Philadelphia Newspapers CEO Brian Tierney told a House subcommittee in April. ${ }^{137}$

By the end of 2010, advertising revenues had not yet rebounded, opening the possibility of further staff layoffs and pay cuts, curtailed circulation, and other measures, including retrenchment at papers across the country. It is unclear whether newspapers will quickly be able to develop a new business model that will allow for the continuation of most existing generalinterest publications, or whether the industry will reorganize as smaller, more targeted productswith readers pulling from a variety of specialized sources for their news.

\footnotetext{
${ }^{130}$ Testimony of Alberto Ibarguen, President John S. and James L. Knight Foundation, Senate Commerce, Science, and Transportation Subcommittee on Communications, Technology, and the Internet, May 6, 2009.

${ }^{131}$ Ibid.

${ }^{132}$ Farhi, Paul, "Public Broadcasting Targeted by House,” Washington Post, June 10, 2005, P. A1. http://www.washingtonpost.com/wp-dyn/content/article/2005/06/09/AR2005060902283.html.

133 “Gov. Gregoire approves tax cut for Washington state newspapers," Seattle Times, May 12, 2009. http://seattletimes.nwsource.com/html/localnews/2009212482_apwanewspapertaxcuts.html.

${ }^{134}$ McGeehan, Patrick, “City Starts Program to Foster Entrepreneurial New Media,” New York Times, July 8, 2009.

${ }^{135}$ Pfanner, Eric, "France Expands Its Financial Support for Newspapers," New York Times, Jan 23, 2009, p. B2.

136 Senate Press Gallery Staff.

${ }^{137}$ Written statement of Brian Tierney, CEO of Philadelphia Newspapers, LLC, House Judiciary Subcommittee on Courts and Competition Policy, April 21, 2009.
} 


\section{Author Contact Information}

Suzanne M. Kirchhoff

Analyst in Industrial Organization and Business skirchhoff@crs.loc.gov, 7-0658 